\title{
Characterization of Some Nigerian Coals for Power Generation
}

\author{
M. Chukwu, C. O. Folayan, G. Y. Pam, and D. O. Obada \\ Department of Mechanical Engineering, Ahmadu Bello University, Zaria 810222, Nigeria \\ Correspondence should be addressed to D. O. Obada; obadavid4@gmail.com
}

Received 30 November 2015; Accepted 31 March 2016

Academic Editor: Kalyan Annamalai

Copyright (c) 2016 M. Chukwu et al. This is an open access article distributed under the Creative Commons Attribution License, which permits unrestricted use, distribution, and reproduction in any medium, provided the original work is properly cited.

\begin{abstract}
Five coal samples from Odagbo (Kogi State), Owukpa (Benue State), Ezimo (Enugu State), Amansiodo (Enugu State), and Inyi (Enugu State) of Nigerian coal deposits were subjected to proximate analysis, ultimate analysis, calorific value determination, and petrographic and thermogravimetric analysis to determine their suitability for power generation. Based on results of tests carried out, Amansiodo coal is a bituminous, low sulphur, and medium ash coal, while Owukpa coal is a subbituminous A, low sulphur, low ash coal rich in huminites, Odagbo coal is a subbituminous B, medium sulphur, low ash coal rich in huminites, Ezimo coal is a subbituminous C, low sulphur, high ash coal, and Inyi coal is a subbituminous C, low sulphur, high ash coal. Between Odagbo and Owukpa subbituminous coals, Owukpa has a lower ignition temperature $\left(283.63^{\circ} \mathrm{C}\right)$ due to its higher volatile matter content $(39.1 \%)$. However, Ezimo subbituminous coal, which has a lower volatile matter (31.1\%), unexpectedly has the same ignition temperature as Owukpa $\left(283.63^{\circ} \mathrm{C}\right)$ due to its higher liptinite content $(7.2 \%)$ when compared with that of Owukpa (2.9\%). The ease of combustion of the coal samples in decreasing order is Odagbo $<$ Owukpa $<$ Inyi $<$ Ezimo $<$ Amansiodo.
\end{abstract}

\section{Introduction}

Access to energy, especially electricity, is a driving force for economic and social development [1]. Coal is the key fuel for generating electricity on almost all continents, with almost all developed and developing countries relying on coal for the stable and secure supply of electricity [2]. Coal also provides a reliable source of electricity and remains the cheapest source of electricity in the world today. The proportion of electricity generated from coal is currently increasing, especially in developing economies [3]. Coal does not presently contribute to Nigeria's electricity generation in spite of its abundant deposits in Nigeria [1]. The proven reserves of coal so far in the country are 639 million tonnes while the inferred reserves are about 2.75 billion tonnes, consisting approximately of $49 \%$ subbituminous, $39 \%$ bituminous, and $12 \%$ lignitic coals [4]. Against the backdrop of severe shortages in much needed supply of electricity, it is inevitable that Nigeria must move from rhetoric to concrete action in the development and addition of coal-fired electricity to the nation's electricity supply mix.

By IEA, the top 10 coal producers in 2011 were (Mt) China 3,576 (46\%), United States 1,004 (13\%), India 586 (8\%), Australia 414 (5\%), Indonesia 376 (5\%), Russia 334 (4\%),
South Africa 253 (3\%), Germany 189 (2\%), Poland 139 (2\%), and Kazakhstan 117 (2\%). In 2011 total coal production was 7,783 million tonnes (Mt) [5]. Top coal producers in 2012 were (Mt) China 3,549, United States 935, India 595, Indonesia 443, Australia 421, Russia 354, South Africa 259, Germany 197, Poland 144, and Kazakhstan 126. In 2012 total coal production was 7,832 Mt. World coal production increased from year 2011 to 2012 [6]. Nigeria still holds large coal reserves estimated to be at least 2 billion metric tons [7].

Over the years, some works have been done on the characterization of Nigerian coals. Nasir et al. [8] reported an experiment using Enugu subbituminous coal of size $850 \mu \mathrm{m}$. The particle size distribution of the coal batch sizes was investigated by feeding the coal over-bed in batches of 0.15 , $0.25,0.35$, and $0.45 \mathrm{~kg} / \mathrm{batch}$. The bed and free-board temperatures were measured using accurate digital thermocouples across the diameter of the bed. The minimum fluidisation velocity was obtained to be 1.64 and $1.91 \mathrm{~m} / \mathrm{s}$ for a coal batch feed of 150 and $450 \mathrm{~g}$, respectively. Jauro and Chukwu [9] investigated three Nigerian coals (Onyeama, Lafia-Obi, and Garin Maiganga) to determine their suitability in developing formed coke for use as blast furnace coke. Parameters that were used include the shatter index expressed as percentage stability and friability and mecum index. The highest 
cumulative percentage stability and the lowest cumulative percentage friability were observed in Lafia-Obi with values of $67.54 \%$ and $32.46 \%$, followed by Onyeama with $66.92 \%$ and $33.08 \%$ and then Garin Maiganga with $55.04 \%$ and $44.96 \%$, respectively. Medium and low temperature carbonization of Onyeama and Lafia-Obi coal samples gave an improved and satisfactory percentage stability and friability for semicokes.

In the search for a Nigerian coking coal, Aderonpe [10] carried out the assessment of blends of high volatile (30\%$36 \%)$ bituminous coals with low volatile $(<20 \%)$ bituminous coals. In another investigation, Onyeama and Okaba coals were reported to be poorly caking and Lafia/Obi to be weakly caking [11]. The cakeability of Enugu coal blended with some imported coals was also studied [11].

Most research work on Nigerian coals is focused on their usefulness in the metallurgical industry. The few research works carried out on Nigerian coals as regards power generation have not comprehensively characterized Nigerian coals based on the contemporary requirements of power plant designers and operators. The usual tests such as proximate analysis, ultimate analysis, calorific value determination, and ash analysis have extensively been carried out. However, contemporary tests required for a comprehensive characterization of Nigerian coals for power generation such as thermogravimetric analysis, petrographic analysis, and drop tube furnace tests, to the best of our knowledge, have rarely been carried out.

Therefore, this paper covers the characterization of coal from five deposits in Nigeria which include Odagbo (Kogi State), Owukpa (Benue State), Ezimo (Enugu State), Amansiodo (Enugu State), and Inyi (Enugu State). Estimated reserves of these deposits are 250, 75, 156, 1000, and 50 million tonnes, respectively. Analyses carried out include determination of proximate analysis, calorific value, ultimate analysis, ash composition, ash fusion temperature (in oxidizing and reducing atmospheres), petrographic analysis, and thermogravimetric analysis. Results of the analyses are compared with specification values derived from both the literature and a survey of coal-fired power plant operators in order to determine the suitability of the coal samples for power generation.

\section{Materials and Methods}

Coal samples were obtained through the Nigerian Coal Corporation, Enugu, for five different deposits in Nigeria, which include Odagbo (Kogi State), Owukpa (Benue State), Ezimo (Enugu State), Amansiodo (Enugu State), and Inyi (Enugu State). The samples were stored in appropriately labeled airtight containers to retain their as-received conditions.

2.1. General Sample Preparation. The principle of mixing and then dividing, using either mechanical or manual methods as described in the International Organization for Standardisation (ISO) 13909-4:2001 specifications, was used to generate a representative pulverised sample of each coal and then used to prepare each sample to the desired analytical specifications using an array of sample preparation equipment. Osborn $10 \times 6$-inch jaw crusher, double roller crusher, and Retsch
ZM200 ultra centrifugal mill were some of the equipment used to reduce the coal samples from a top size of $150 \mathrm{~mm}$ to a suitable size distribution range of $150-212 \mu \mathrm{m}$. An automatic sieve shaker was used for sieving the samples to the desired size distribution required for each test, while a hand rifle was used to split the samples into representative subsamples.

2.2. Proximate Analysis. $1 \mathrm{~g}$ of each coal sample passing a $212 \mu \mathrm{m}$ test sieve was used for proximate analysis. Moisture content was analysed using the air oven method based on South African National Standards (SANS) 5925:2007 specifications with a LABCON air oven. Volatile matter was determined based on ISO 562:1998 with a volatile furnace manufactured by Ultra-furn (SA) (PTY) Ltd. Ash content was analysed based on ISO 1171:1997 using a LENTON programmable furnace. Fixed carbon was calculated by difference using the formula

$$
\begin{aligned}
& \text { \% Fixed Carbon } \\
& \begin{array}{l}
=100 \\
\quad-(\% \text { Moisture }+\% \text { Ash }+\% \text { Volatile Matter }) .
\end{array}
\end{aligned}
$$

2.3. Ultimate Analysis. $1 \mathrm{~g}$ of coal sample passing through a sieve having an aperture of $212 \mu \mathrm{m}$ was used for ultimate analysis in a LECO TRUSPEC CHN elemental determining device based on ISO 12902-CHN instrumental method. Oxygen was calculated by difference on an air-dried basis as follows:

$$
\begin{aligned}
& \text { Oxygen }(\%)=100-(\text { Carbon }+ \text { Hydrogen } \\
& + \text { Nitrogen + Ash + Moisture })
\end{aligned}
$$

2.4. Calorific Value, Total Sulphur, and Ash Analyses. $1 \mathrm{~g}$ of coal sample passing through a sieve with an aperture of $212 \mu \mathrm{m}$ was used to determine gross calorific value in a Parr 6400 Isoperibol Calorimeter based on ISO 1928:1995 specifications. For the total sulphur determination, $0.35 \mathrm{~g}$ of coal sample passing through a sieve with an aperture of $212 \mu \mathrm{m}$ was used to determine total sulphur using infrared spectroscopy method as specified by ISO 19579. A LECO S144 dual range sulphur detector was the equipment used. The ash analyses evaluation entailed the heating of the coals to about $815^{\circ} \mathrm{C}$ at a constant weight under standard conditions to form ash, a process referred to as "bulk ashing," using the LENTON Ash Furnace. Ash composition analysis was carried out using the ASTM D-4326 X-ray fluorescence method. Ash fusion temperatures in oxidizing and reducing atmospheres were investigated using ISO 540:2008 specifications in a CARBOLITE CAF Digital Furnace with a maximum operating temperature of $1550^{\circ} \mathrm{C}$. Carbon dioxide gas was used for the oxidizing atmosphere, while a combination of carbon dioxide and hydrogen gases was used for the reducing atmosphere.

2.5. Petrographic Analysis. The method used is that recommended by the International Committee for Coal and Organic Petrology (ICCP) as published in ISO 7404 
handbooks. Coal samples passing a sieve of $850 \mu \mathrm{m}$, each weighing $15 \mathrm{~g}$, were used to produce $30 \mathrm{~mm}$ diameter particulate blocks using M Resin (epoxy resin) mixed with HY 956 modified polyamide hardener in a ratio of $5: 1$. The blocks were ground and polished in a SAPHIR 520 grinder with the aid of abrasive cloth and colloidal silica liquid. The highly polished particulate block representing a sample was coated with nondrying immersion oil and placed under an Ortholux 32x lens microscope. An automatic point counter moves the microscope crosshairs over the polished surface of the particulate block at traverse spacing of $0.4 \mathrm{~mm}$ and intervals between the traverses of $0.5 \mathrm{~mm}$. A point is an observation of a portion of the particulate block under the crosshair. At least 500 points (excluding binding resin and visible minerals) were counted by tapping on the counter key allotted to each maceral spotted. At the end of 500 counts, the total count obtained for each maceral was used to obtain the percentage maceral composition of each coal sample.

2.6. Thermogravimetric Analysis. The combustion in air method was used for this analysis. The instrument used for this analysis was an SDT Q600 simultaneous DSC/TGA instrument. This is capable of performing both differential scanning calorimetry (DSC) and thermogravimetric analysis (TGA) simultaneously. Coal samples passing through a test sieve with an aperture of $212 \mu \mathrm{m}$ were used for this test. $25 \mathrm{mg}$ of the coal sample was carefully weighed and loaded into the instrument's lidless alumina crucible with a volume of $90 \mu \mathrm{L}$. The sample was heated in air from $25^{\circ} \mathrm{C}$ to $1000^{\circ} \mathrm{C}$ at a heating rate of $10^{\circ} \mathrm{C} / \mathrm{min}$ and an air flow rate of $50 \mathrm{~mL} / \mathrm{min}$. The change in weight of the sample was automatically recorded until there was no further change in weight. The residue in the crucible represents the ash content of the sample. The ignition temperature on the thermograms for the various coals was calculated following this procedure: through the DSC (differential thermogravimetric) peak point, a vertical line was made upward to meet the TG oblique line. A tangent line to TG curve was created which met the extended TG initial level line. The vertical line which projects downwards and meets the cross axle is defined as the ignition temperature. This is read from the corresponding value on the temperature axis.

Correlation Coefficient between Some Properties and Calorific Value of Coal. Equation (3) was used to investigate the correlation of the results obtained for some of the properties of the coals sampled. Results for fixed carbon, volatile matter, carbon, and hydrogen were correlated against calorific value:

$$
r=\frac{n \sum(x y)-\left(\sum x\right)\left(\sum y\right)^{2}}{\sqrt{ }\left\{\left[n \sum x^{2}-\left(\sum x\right)^{2}\right]\left[n \sum y^{2}-\left(\sum y^{2}\right)\right]\right\}},
$$

where $r$ is correlation coefficient, $n$ is number of samples, $x$ and $y$ are variables (properties) investigated.

\section{Results and Discussion}

3.1. Proximate Analysis. Results obtained from proximate analyses of the five coal samples are shown in Table 1 on an airdried basis, while the calculated fuel ratio of each sample is
TABLE 1: Results of proximate analyses of the five coal samples.

\begin{tabular}{lccccc}
\hline \multirow{2}{*}{ Properties } & \multicolumn{5}{c}{ Samples } \\
& Odagbo & Owukpa & Ezimo & Amansiodo Inyi \\
\hline Inherent moisture (\%) & 14.9 & 11.5 & 6.6 & 5.4 & 3.8 \\
Ash content (\%) & 5.3 & 3.3 & 23.4 & 8.6 & 30.4 \\
Volatile matter, VM (\%) & 38.7 & 39.1 & 31.1 & 38.1 & 29.9 \\
Fixed carbon, FC (\%) & 41.1 & 46.1 & 38.9 & 47.9 & 35.9 \\
\hline
\end{tabular}

shown in Figure 2. Fixed carbon was calculated by difference using (1).

The inherent moisture contents range from $3.80 \%$ to $14.9 \%$. The Odagbo coal sample had the highest moisture content of 14.9\%, followed by Owukpa, Ezimo, Amansiodo, and then Inyi coal samples with $11.5 \%, 6.6 \%, 5.4 \%$, and $3.8 \%$, respectively. There is no much difference between the volatile matter contents of Odagbo, Owukpa, and Amansiodo coal samples. The Inyi coal sample had the lowest volatile matter content (29.90\%). The highest fixed carbon content of $47.9 \%$ was recorded in Amansiodo coal sample, followed by Owukpa, Odagbo, Ezimo, and Inyi coal samples with values of $46.1 \%, 41.1 \%, 38.9 \%$, and $35.9 \%$, respectively. The Amansiodo coal sample had the highest gross calorific value of $27.48 \mathrm{MJ} / \mathrm{kg}$, followed by the Owukpa coal sample with $26.51 \mathrm{MJ} / \mathrm{kg}$, the Odagbo coal sample with $22.60 \mathrm{MJ} / \mathrm{kg}$, the Ezimo coal sample with $20.96 \mathrm{MJ} / \mathrm{kg}$, and then the Inyi coal sample with $19.39 \mathrm{MJ} / \mathrm{kg}$. It is noteworthy that Inyi coal sample with the lowest inherent moisture content $(3.8 \%)$ would be the easiest to handle and store followed by Amansiodo (5.4\%), Ezimo (6.6\%), Owukpa (11.5\%), and then Odagbo (14.9\%) coal samples.

Ash content affects coal and ash handling systems, pulverisers (abrasion), furnace, superheater, reheater, economiser, soot-blowing intervals (slagging and fouling propensity, erosion, and corrosion), pollution control equipment, and unburnt carbon in ash [13]. Owukpa coal sample with the lowest ash content (3.3\%) would cost less in terms of investment in ash handling equipment and pulveriser abrasion followed by Odagbo (5.3\%), Amansiodo (8.6\%), Ezimo (23.4\%), and Inyi (30.4\%) coal samples.

The volatile matter content of coal affects storage behaviour (oxidation, danger of spontaneous combustion, and loss of heating value), pulveriser outlet temperature and required fineness for pulverisation, burner settings, furnace, combustion behaviour, and efficiency (ignition, flame shape and stability, and burnout and carbon content of fly ash) [13]. Inyi coal sample with the lowest volatile matter (29.9\%) would have the least danger of spontaneous combustion. This is followed by Ezimo (31.1\%), Amansiodo (38.1\%), Owukpa (39.1\%), and Odagbo (38.7\%) samples.

The fuel ratio has also been computed by the ratio of fixed carbon to volatile matter; this is as represented in Figure 1. The ratio of fixed carbon to volatile matter (fuel ratio) indicates the ease of ignition and burnout, but the heat content of the volatile matter is a more reliable guide to ignition. The volatile matter content influences $\mathrm{NO}_{x}$ formation. Generally for the same burner and constant nitrogen content, the higher the 


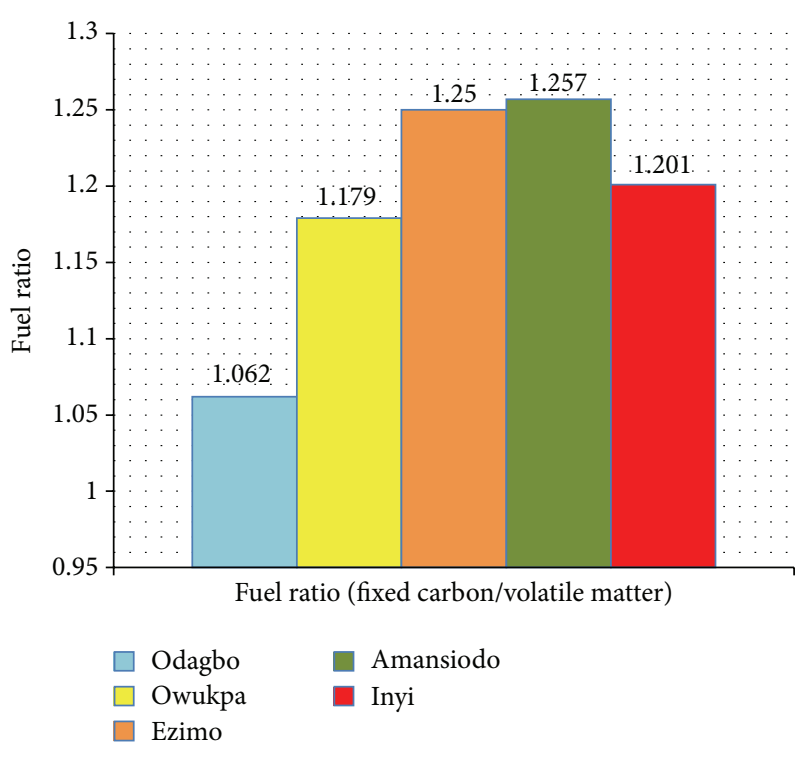

FIGURE 1: Fuel ratio of the five coal samples.

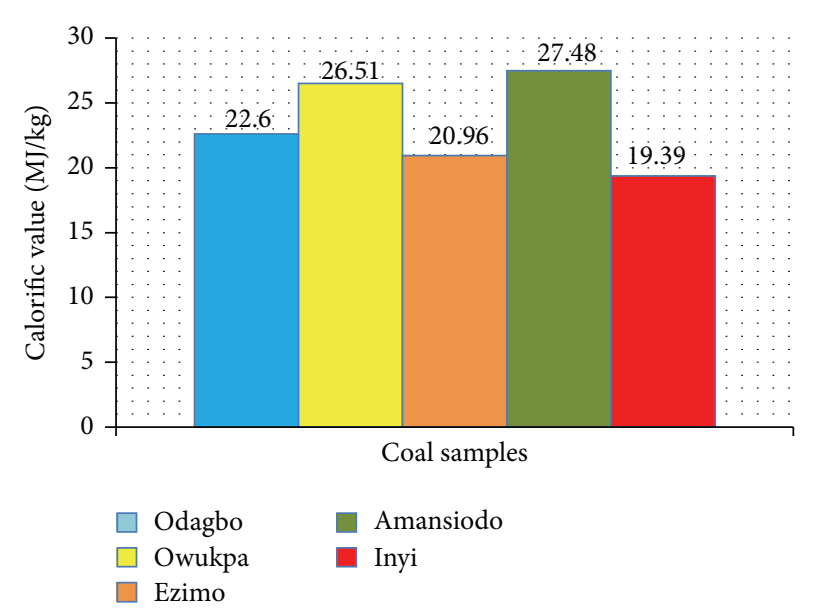

FIgURE 2: Calorific value of the five coal samples.

volatile matter, the lower the $\mathrm{NO}_{x}$. It can be seen from Figure 1 that Amansiodo possesses the highest fuel ratio.

3.2. Ultimate Analysis. Results obtained from the ultimate analysis carried out on the five coal samples were evaluated on air-dried basis. Oxygen was calculated by difference on an air-dried basis using (2). The elemental composition of carbon, hydrogen, nitrogen, sulphur, and oxygen in the coal samples is shown in Table 2. The percentages of the elemental carbon of Odagbo, Owukpa, Ezimo, Amansiodo, and Inyi coal samples were as follows: $62.16 \%, 67.82 \%, 54.21 \%, 66.95 \%$, and $49.27 \%$, and those of hydrogen are $5.87 \%, 5.88 \%, 4.42 \%$, $5.62 \%$, and $4.19 \%$. Ezimo and Inyi coal samples had low total sulphur contents of $0.56 \%$ each, respectively, while Odagbo sample had the highest value of $1.07 \%$. The oxygen contents of the coal samples fell between $9.34 \%$ and $10.93 \%$. The Odagbo coal sample had the lowest oxygen content of $9.34 \%$, followed by Owukpa, Ezimo, Inyi, and Amansiodo coal samples with $9.47 \%, 9.59 \%, 10.53 \%$, and $10.93 \%$, respectively.
TABLE 2: Results of ultimate analyses of the five coal samples.

\begin{tabular}{lccccc}
\hline \multirow{2}{*}{ Elements } & \multicolumn{5}{c}{ Samples } \\
& Odagbo & Owukpa & Ezimo & Amansiodo & Inyi \\
\hline Carbon (\%) & 62.16 & 67.82 & 54.21 & 66.95 & 49.27 \\
Hydrogen (\%) & 5.87 & 5.88 & 4.42 & 5.62 & 4.19 \\
Nitrogen (\%) & 1.37 & 1.43 & 1.22 & 1.58 & 1.24 \\
Total sulphur (\%) & 1.07 & 0.60 & 0.56 & 0.92 & 0.56 \\
Oxygen (\%) & 9.34 & 9.47 & 9.59 & 10.93 & 10.53 \\
\hline
\end{tabular}

The Amansiodo coal sample had the highest nitrogen content of $1.58 \%$, followed by the Owukpa coal sample with $1.43 \%$, the Odagbo coal sample with $1.37 \%$, and the Inyi coal sample with $1.24 \%$, while the Ezimo had the lowest value of $1.22 \%$. Carbon and hydrogen are the major combustible constituents of coal, and both of them are high in the coal samples. The higher the carbon content, the higher the calorific value and the better the quality of the coal for power generation.

3.3. Calorific Value. Results obtained from the gross calorific value determination carried out on the five coal samples are shown in Figure 2. The calorific value gives the heating value or the heat of combustion of a substance. It has been suggested that the calorific value of power plant coals is in the range of $9.5 \mathrm{MJ} / \mathrm{kg}$ to $27 \mathrm{MJ} / \mathrm{kg}$ [14]. Thus, all the coal samples would be suitable for power generation. The Amansiodo coal sample, with the highest heating value of $27.48 \mathrm{MJ} / \mathrm{kg}$, would be the best for heating and power generation.

The heat of combustion of any organic compound is associated with the bond energies between the atoms forming the chemical structure of the compound and therefore with the character of the bonds. However, in spite of the absence of fundamental scientific validation, the possibility that the heat of combustion might be calculated for solid fuels (e.g., coals) with fair accuracy from elementary composition alone has led many researchers to establish empirical correlations from their commonly measured characteristics. Those correlations are often expressed in the form of linear combinations of the weight percentages of the atom elements $\mathrm{C}, \mathrm{H}$, and $\mathrm{O}$, sometimes expanded to $\mathrm{S}$ and $\mathrm{N}$. The reason is that major elements in the chemical composition of fossil fuels are actually limited to $\mathrm{C}, \mathrm{H}, \mathrm{O}, \mathrm{N}$, and $\mathrm{S}$ in their organic part [15]. A formula for the gross heating value (HV) of fossil fuels was developed by [16]. The empirical equation was expressed as follows:

$$
\begin{aligned}
\mathrm{HV}, \mathrm{KJ} / \mathrm{kg}= & 35.160 \mathrm{C}+116.225 \mathrm{H}-11.090 \mathrm{O} \\
& +6.280 \mathrm{~N}+10.465 \mathrm{~S}
\end{aligned}
$$

Oxygen has a negative coefficient because it ties up some of the carbon and hydrogen in the form of $\mathrm{CO}, \mathrm{H}_{2} \mathrm{O}$, phenols $(\mathrm{OH})$, and so forth. Depending upon the chemical functional groups of the fuels, the heating values may differ. Generally, the greater the oxygen percentage, the lower the percentage of $\mathrm{C}$ and $\mathrm{H}$ available for combustion and hence the lower the heating value [17]. A comparison of heating rates of the sample coals estimated from the Boie equation is given in Table 3. 
TABLE 3: Comparison of heating values of sample coals estimated from the Boie equation with measured values.

\begin{tabular}{lcccccccc}
\hline \multirow{2}{*}{ Samples } & \multicolumn{3}{c}{ Ultimate analysis, \% dry weight } & \multicolumn{3}{c}{ Heating value MJ/kg } \\
& Carbon & Hydrogen & Oxygen & Nitrogen & Sulphur & $\begin{array}{c}\text { Measured } \\
\text { MJ } / \mathrm{kg}\end{array}$ & $\begin{array}{c}\text { Estimated } \\
\text { MJ } / \mathrm{kg}\end{array}$ \\
\hline Odagbo & 62.16 & 5.87 & 9.34 & 1.37 & 1.07 & 22.60 & 27.00 & +19.46 \\
Owukpa & 67.82 & 5.88 & 9.47 & 1.43 & 0.60 & 26.51 & 29.78 & +12.33 \\
Ezimo & 54.21 & 4.42 & 9.59 & 1.22 & 0.56 & 20.96 & 23.26 & +9.88 \\
Amansiodo & 66.95 & 5.62 & 10.93 & 1.58 & 0.92 & 27.48 & 29.02 & +5.60 \\
Inyi & 49.27 & 4.19 & 10.53 & 1.24 & 0.56 & 19.39 & 22.82 & +17.68 \\
\hline
\end{tabular}

TABLE 4: Results of ash composition tests of the five coal samples.

\begin{tabular}{lccccc}
\hline Constituents & Odagbo & Owukpa & Ezimo & Amansiodo & Inyi \\
\hline $\mathrm{Al}_{2} \mathrm{O}_{3}(\%)$ & 25.78 & 27.60 & 20.76 & 29.13 & 19.02 \\
$\mathrm{CaO}(\%)$ & 2.15 & 0.95 & 0.60 & 0.34 & 0.05 \\
$\mathrm{Cr}_{2} \mathrm{O}_{3}(\%)$ & 0.03 & 0.03 & 0.02 & 0.04 & 0.01 \\
$\mathrm{Fe}_{2} \mathrm{O}_{3}(\%)$ & 7.98 & 4.48 & 2.93 & 6.90 & 1.70 \\
$\mathrm{~K}_{2} \mathrm{O}(\%)$ & 0.31 & 0.06 & 1.13 & 1.32 & 0.36 \\
$\mathrm{MgO}(\%)$ & 1.31 & 0.04 & 0.16 & 0.35 & 0.06 \\
$\mathrm{MnO}(\%)$ & 0.41 & 0.03 & 0.04 & 0.05 & - \\
$\mathrm{Na}_{2} \mathrm{O}(\%)$ & 0.07 & 0.02 & 0.03 & 0.06 & 0.01 \\
$\mathrm{P}_{2} \mathrm{O}_{5}(\%)$ & 0.06 & 0.77 & 0.21 & 0.22 & 0.06 \\
$\mathrm{SiO}_{2}(\%)$ & 56.81 & 61.64 & 70.92 & 58.94 & 75.92 \\
$\mathrm{TiO}_{2}(\%)$ & 1.98 & 2.98 & 2.29 & 2.13 & 2.29 \\
$\mathrm{~V}_{2} \mathrm{O}_{5}(\%)$ & 0.09 & 0.03 & 0.02 & 0.04 & 0.02 \\
$\mathrm{ZrO}_{2}(\%)$ & 0.10 & 0.13 & 0.11 & 0.07 & 0.15 \\
$\mathrm{Ba}_{2}(\%)$ & 0.20 & 0.17 & 0.08 & 0.06 & 0.02 \\
$\mathrm{Sr}(\%)$ & 0.04 & 0.13 & 0.04 & 0.05 & 0.01 \\
$\mathrm{SO}_{3}(\%)$ & 1.74 & - & 0.28 & - & - \\
\hline
\end{tabular}

TABLE 5: Results of ash fusion temperature test (in oxidizing atmosphere) of the five coal samples.

\begin{tabular}{lccccc}
\hline Temperatures & \multicolumn{5}{c}{ Samples } \\
& Odagbo & Owukpa & Ezimo & Amansiodo & Inyi \\
\hline $\begin{array}{l}\text { Initial deformation } \\
\left({ }^{\circ} \mathrm{C}\right)\end{array}$ & 1461 & $>1550$ & $>1550$ & $>1550$ & $>1550$ \\
Softening $\left({ }^{\circ} \mathrm{C}\right)$ & 1489 & $>1550$ & $>1550$ & $>1550$ & $>1550$ \\
Hemispherical $\left({ }^{\circ} \mathrm{C}\right)$ & 1518 & $>1550$ & $>1550$ & $>1550$ & $>1550$ \\
Fluid $\left({ }^{\circ} \mathrm{C}\right)$ & $>1550$ & $>1550$ & $>1550$ & $>1550$ & $>1550$ \\
\hline
\end{tabular}

3.4. Ash Analyses. Results obtained from the ash composition test of the five coals samples using the X-ray fluorescence (XRF) technique are shown in Table 4.

Results obtained from the ash fusion temperature test (in oxidizing atmosphere) of the five coals samples are shown in Table 5.

Results obtained from the ash fusion temperature tests of the five coals samples are shown in Table 6.

3.5. Petrographic and Thermogravimetric Analysis. The results obtained from the petrographic analysis giving the maceral composition of the coal samples are shown in
TABLE 6: Results of ash fusion temperature test (in reducing atmosphere) of the five coal samples.

\begin{tabular}{lccccc}
\hline Temperature & \multicolumn{5}{c}{ Samples } \\
& Odagbo & Owukpa & Ezimo & Amansiodo & Inyi \\
\hline $\begin{array}{l}\text { Initial deformation } \\
\left({ }^{\circ} \mathrm{C}\right)\end{array}$ & 1519 & $>1550$ & $>1550$ & $>1550$ & $>1550$ \\
Softening $\left({ }^{\circ} \mathrm{C}\right)$ & 1528 & $>1550$ & $>1550$ & $>1550$ & $>1550$ \\
Hemispherical $\left({ }^{\circ} \mathrm{C}\right)$ & 1540 & $>1550$ & $>1550$ & $>1550$ & $>1550$ \\
Fluid $\left({ }^{\circ} \mathrm{C}\right)$ & $>1550$ & $>1550$ & $>1550$ & $>1550$ & $>1550$ \\
\hline
\end{tabular}

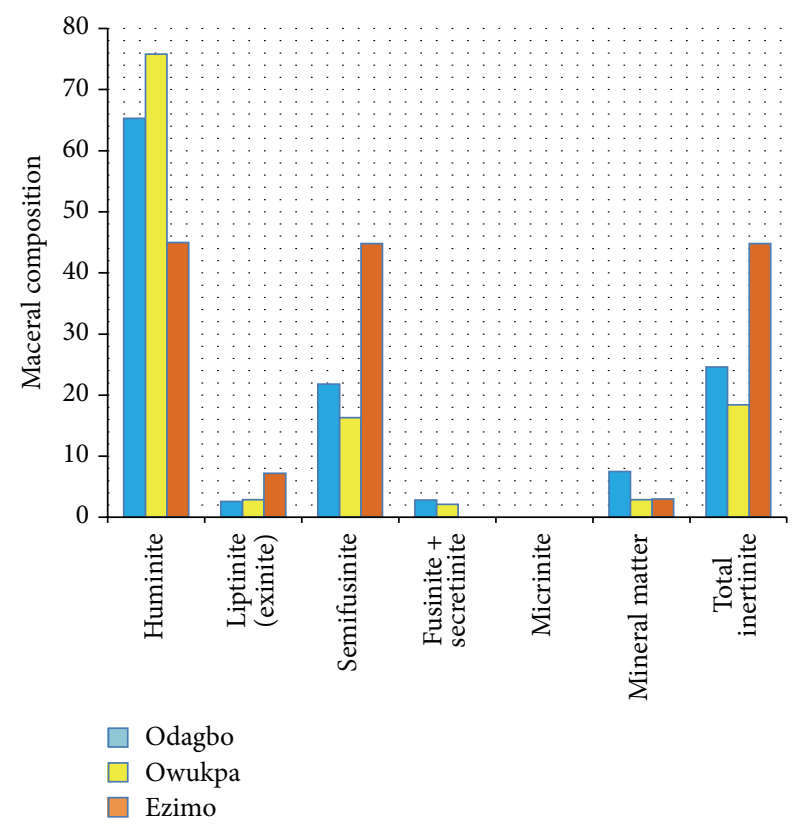

FIgURE 3: Petrographic analyses.

Figure 3. Based on the conclusion of [18] that a fuel with a higher fuel ratio is more difficult to burn than a fuel with a lower fuel ratio, from Figure 3, the ease of combustion of the coal samples in decreasing order is Odagbo (1.062), Owukpa (1.179), Inyi (1.201), Ezimo (1.250), and Amansiodo (1.257). This is in agreement with the findings of [19] that coals with lower peak maxima temperatures $\left(T_{p}\right)$ can generally be ignited and burned in an easier way.

The peak temperatures at maximum weight loss rate $\left(T_{p}\right)$ obtained during thermogravimetric analysis for three of the coal samples shown in Figure 4 were Odagbo, $405^{\circ} \mathrm{C}$, 


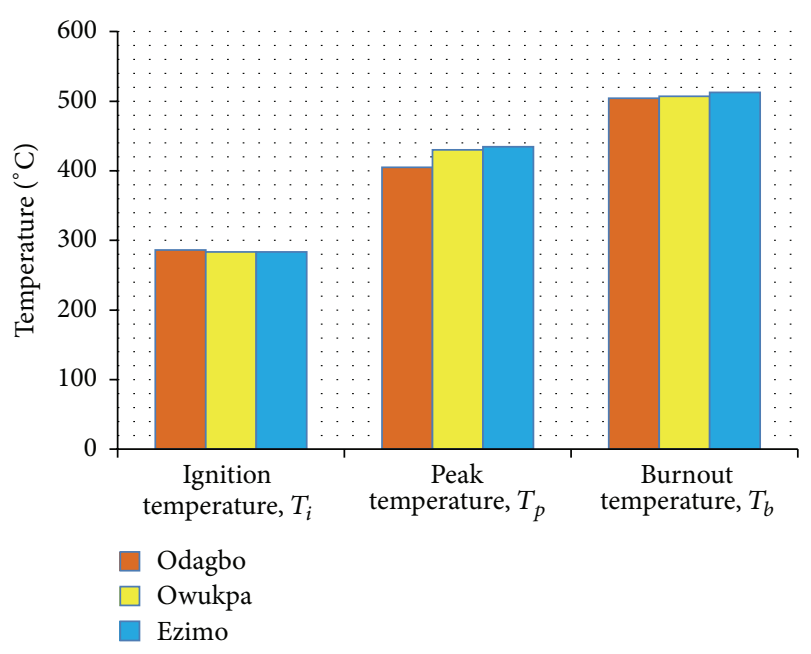

FIGURE 4: Characteristic temperatures of the coal samples.

Owukpa, $430^{\circ} \mathrm{C}$, and Ezimo, $434^{\circ} \mathrm{C}$, in increasing order, which is also a decreasing order of ease of combustion.

The characteristic temperatures obtained for the coal samples are as shown in Figure 4.

The combustion profiles obtained for Odagbo, Owukpa, and Ezimo coal samples were used to derive characteristic temperatures. The characteristic temperatures were designated as follows [20]:

$T_{i}$ is initial (or ignition) temperature where mass loss reaches a rate of $1 \%$ per minute.

$T_{p}$ is peak temperature at the maximum weight loss rate, indicating coal combustibility.

$T_{b}$ is burnout temperature where DTG profile reaches a $1 \%$ combustion rate at the tail-end of the profile, indicating the completion of sample oxidation.

Ignition temperature $\left(T_{i}\right)$ values obtained during thermogravimetric analyses (Figure 4 ) and volatile matter values obtained during proximate analyses (Table 1) for Odagbo and Owukpa coals agree with the conclusions of [20] that the ignition temperature of coal increases with decreasing volatile matter content. However, this conclusion is negated by the value for Ezimo coal, which ought to have the highest ignition temperature value since it possesses the lowest volatile matter content $(31.1 \%)$ of the three samples analysed. This anomaly would be due to its relatively high liptinite content $(7.2 \%)$ as compared to Odagbo $(2.6 \%)$ and Owukpa coals (2.9\%) as shown in Figure 3. This conclusion is based on findings by [20] that the ignition temperatures of maceral groups increase in order of liptinite (exinite)vitrinite-inertinite. In addition, [21] also summarised that research and development conducted over the past five years have indicated that organic matter (macerals) significantly influences combustion behaviour, ignition, and flame stability.

Crelling et al. [22] found out during TGA studies that, of the three maceral groups, exinite (liptinite) has the highest burnout temperature. This is confirmed by the results of petrographic analysis showing liptinite content of the samples as Odagbo 2.6\%, Owukpa 2.9\%, and Ezimo 7.2\%. Figures 57 show the thermograms for the thermogravimetric analysis (TGA) and the derivative thermogravimetric (DSC) curves for Odagbo, Owukpa, and Ezimo coals, respectively. These three coals were selected based on their liptinite content.

For the three samples under oxidation in air, the initial mass loss was also mainly led by water evaporation (exothermic peak at initial temperature). As a result of oxygen uptake and formation of solid oxygenated complexes, the sample mass starts to increase. After reaching the maximum, the sample mass tends to decrease with the further increase in temperature. This is a sign to indicate the acceleration in the rate of thermal decomposition (endothermic) reactions. On one hand, it makes the sample mass decrease; on the other hand, the heat absorbed by the thermal decomposition of unstable oxygenated complexes offsets in part the heat evolved by the oxygen chemisorption, thereby reducing the rate of heat flow. The DSC curve rebounds again after slight decrease, which is assigned to the significant mass loss shown in the TG curve. This phenomenon suggests that another exothermic reaction comes into action at this stage. The variations of the TG and DSC curves for the sample heated in aerial atmosphere are essentially related to the multiple reactions that occur during the oxidation process.

Figure 5 shows mass depletion of the Odagbo coal with a corresponding weight loss of $20.16 \%$ at a temperature of $25.09^{\circ} \mathrm{C}$. This is as a result of physically absorbed water. At a temperature of $220^{\circ} \mathrm{C}$ to $480^{\circ} \mathrm{C}$ another mass depletion was observed which can be as a result of volatile matter burning out. The TG profile became stable as from that temperature to $1000^{\circ} \mathrm{C}$. The DSC curves show a very sharp exothermic peak at the $50^{\circ} \mathrm{C}$ mark, which is as a result of giving out heat after physically absorbed water was released. Another exothermic peak was observed at $405.12^{\circ} \mathrm{C}$ which could be as a result of coal sample giving out heat when all the evaporation effect is over. The burnout temperature $T_{b}$ which indicates the end of sample oxidation is least for Odagbo coal with a temperature of $504.60^{\circ} \mathrm{C}$.

Figure 6 shows mass depletion of the Owukpa coal with a corresponding weight loss of $14.90 \%$ at a temperature of $24.51^{\circ} \mathrm{C}$. This also is as a result of physically absorbed water inherent in the sample. At a temperature of $220^{\circ} \mathrm{C}$ to $500^{\circ} \mathrm{C}$ another mass depletion was observed which can be as a result of volatile matter burning out. The TG profile became stable as from that temperature to $1000^{\circ} \mathrm{C}$. The DSC curves show a very sharp exothermic peak $75^{\circ} \mathrm{C}$ which is as a result of giving out heat after physically absorbed water was released. Another exothermic peak was observed at $430.12^{\circ} \mathrm{C}$ which could be as a result of coal sample giving out heat when all the evaporation effect is over. The burnout temperature $T_{b}$ which indicates the end of sample oxidation is least for Odagbo coal with a temperature of $507.23^{\circ} \mathrm{C}$.

Figure 7 shows mass depletion of the Ezimo coal with a corresponding weight loss of $8.79 \%$ at a temperature of $24.51^{\circ} \mathrm{C}$. This also is as a result of physically absorbed water burning out. At a temperature of $249.43^{\circ} \mathrm{C}$ to $500^{\circ} \mathrm{C}$ another mass depletion was observed which can be as a result of volatile matter burning out. The TG profile became stable as from that temperature to $1000^{\circ} \mathrm{C}$. The DSC curves 


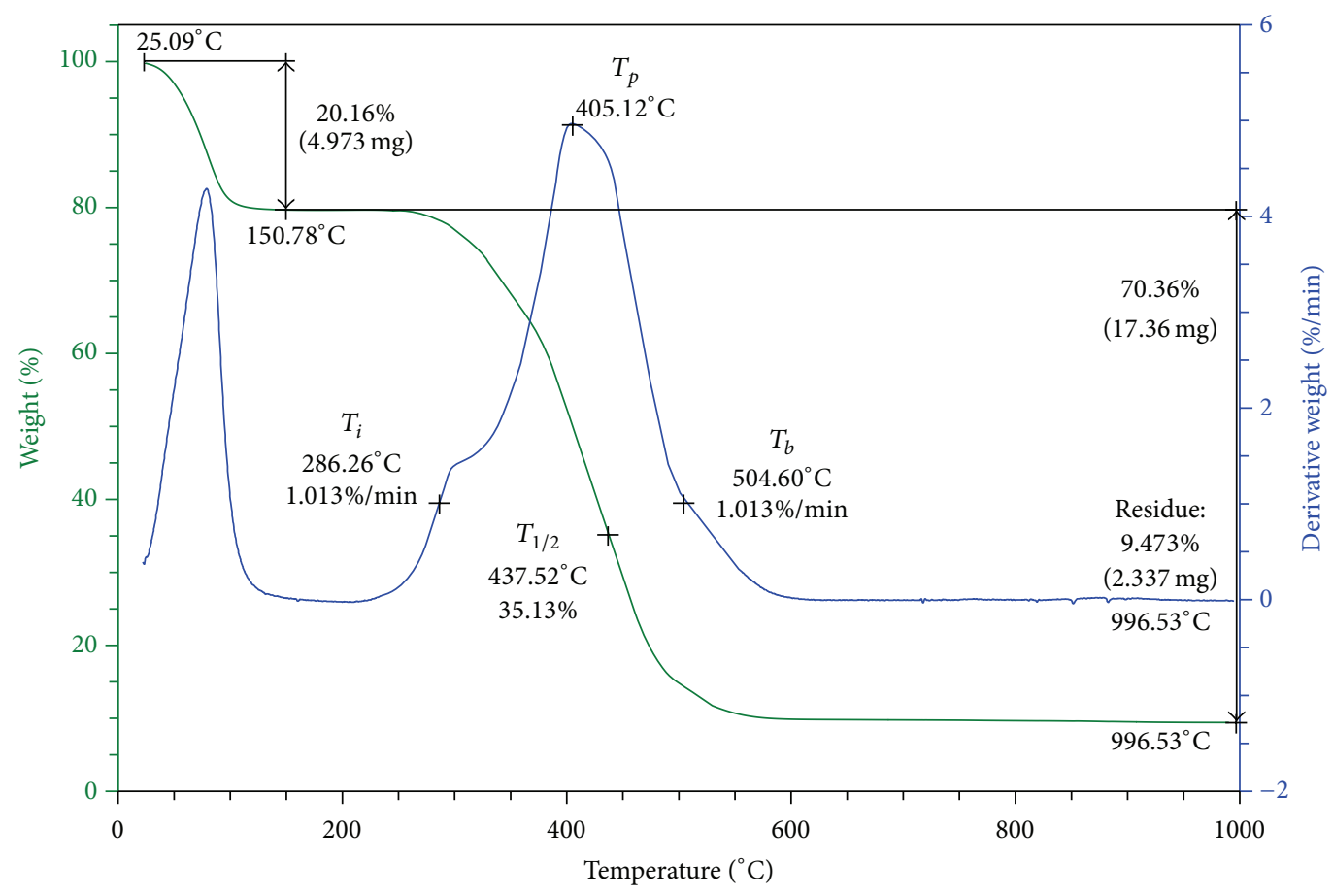

FIGURE 5: TGA/DSC combustion thermogram for Odagbo coal.

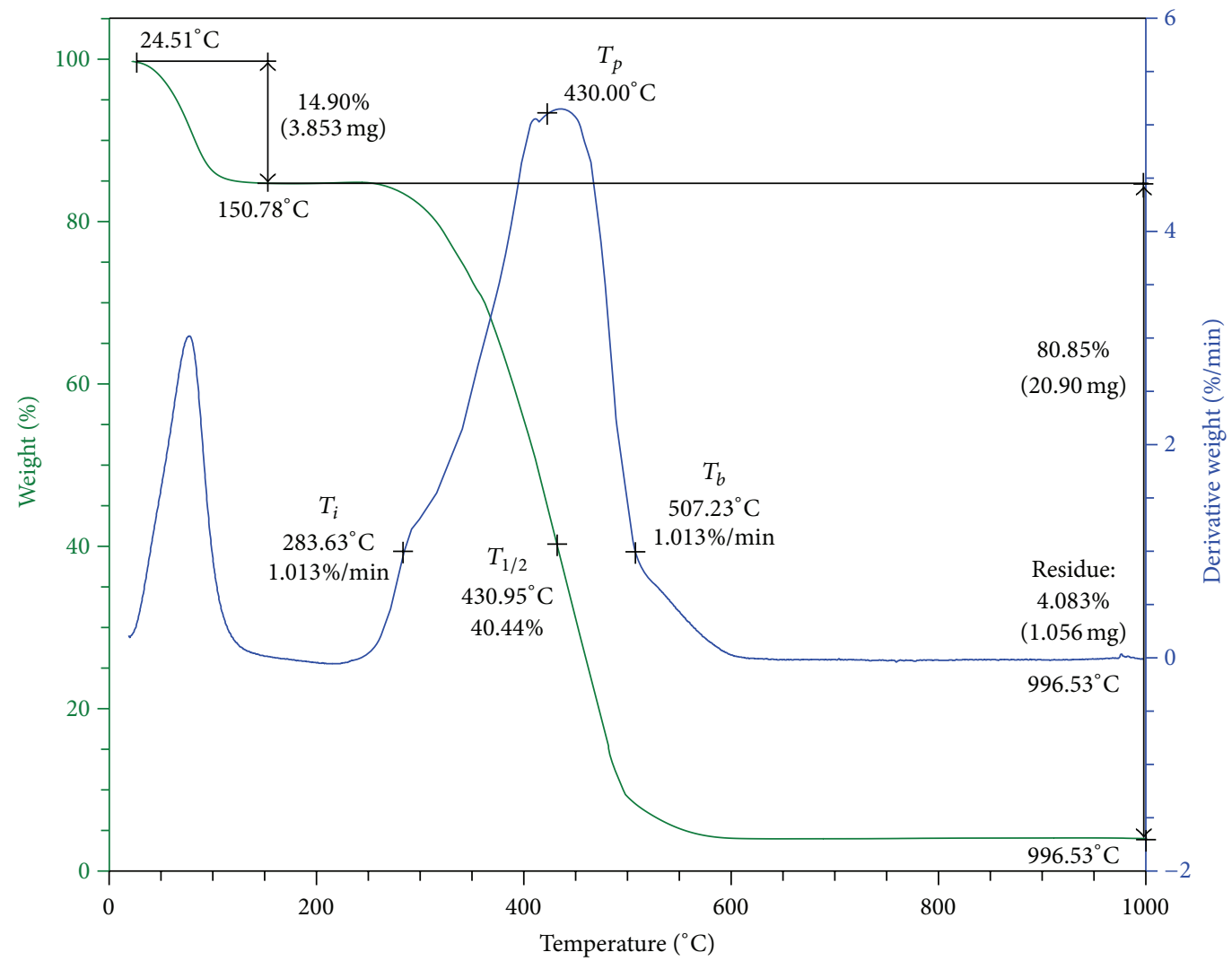

FigURE 6: TGA/DSC combustion thermogram for Owukpa coal. 


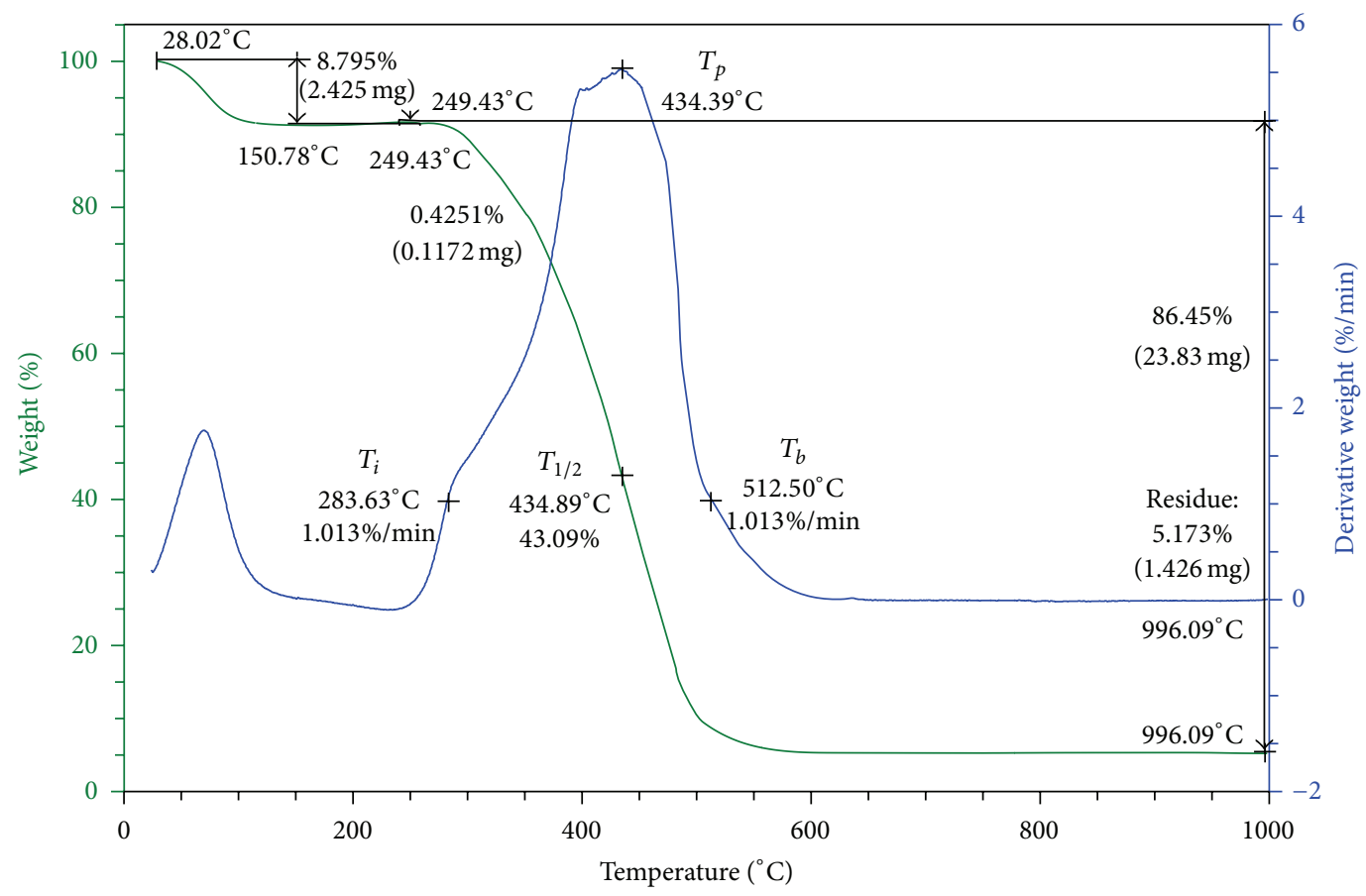

FIGURE 7: TGA/DSC combustion thermogram for Ezimo coal.

show a very sharp exothermic peak at about $78^{\circ} \mathrm{C}$ which is as a result of giving out heat after physically absorbed water was released. Another exothermic peak was observed at $434.39^{\circ} \mathrm{C}$ which could be as a result of coal sample giving out heat when all the evaporation effect is over. The burnout temperature $T_{b}$ which indicates the end of sample oxidation is highest for Ezimo coal with a temperature of $512.50^{\circ} \mathrm{C}$.

The four stages of coal oxidation are water evaporation, oxygen chemisorption, significant decomposition reactions, and the stage dominated by direct burn-off reaction. Meanwhile, the mass loss led by water evaporation is much larger than the mass increase due to oxygen adsorption, thereby resulting in the observed decline in the TG curve. At the stage of oxygen chemisorption, the internal coal pores begin to be exposed to the oxidation medium because of water removal; hence, the rate of chemisorption increases. At this stage, the decomposition of unstable oxygenated complexes does occur and the amount of heat evolved is the compromised result of the instantaneous heat of exothermic chemisorption reactions and that of endothermic decomposition reactions. Given that thermal decomposition of unstable oxygenated complexes is a relatively slow process at temperatures between initial temperature and peak temperature, the amount of heat released increases with the temperature rise, which has been displayed by the DSC curves of all samples. Based on the peak temperature at the maximum weight loss rate, which indicates coal combustibility, Ezimo coal seems to be more combustible than Odagbo and Owukpa coals by reason of the value of peak temperature which stood as $434.39^{\circ} \mathrm{C}$ compared to $405.12^{\circ} \mathrm{C}$ for Odagbo coal and $430.12^{\circ} \mathrm{C}$ for Owukpa coal as represented on the combustion thermograms.
TABLE 7: Correlation between some coal properties and calorific value.

\begin{tabular}{lc}
\hline Coal property & Correlation coefficient, $r$ \\
\hline Fixed carbon & 0.998 \\
Volatile matter & 0.834 \\
Carbon & 0.949 \\
Hydrogen & 0.801 \\
\hline
\end{tabular}

3.6. Correlation of Some Properties and the Calorific Value of the Sampled Coals. Using (3), correlation coefficients $(r)$ between some of the properties and gross calorific values were obtained for the five coal samples and the results are as shown in Table 7.

Correlation of Properties. From Table 7, for the coal samples analysed, the correlation between fixed carbon content and calorific value of coal is the strongest. This means that the fixed carbon content of the coal samples contributes the strongest to the calorific value of the coals. This is followed by carbon, volatile matter, and hydrogen contents in decreasing order.

Ranking of Analysed Coal Samples Using ASTM Classification Criteria. Using results of proximate analyses and calorific values, the five coal samples were ranked based on ASTM D388 specifications. The fixed carbon $(<69 \%)$ and volatile matter $(>31 \%)$ values obtained imply that the coals may only be ranked using the heating value $(\mathrm{Btu} / \mathrm{lb})$ parameter.

Table 8 shows that Amansiodo coal is a bituminous high volatile $\mathrm{C}$ coal and Owukpa coal a subbituminous A coal. Odagbo coal is a subbituminous B coal, while Ezimo and 
TABLE 8: Ranking of five coal samples using the ASTM classification.

\begin{tabular}{|c|c|c|c|c|c|c|}
\hline \multirow[b]{2}{*}{ Coal rank } & \multirow{2}{*}{$\begin{array}{l}\text { Heating value criteria (Btu/lb) } \\
\qquad[12]\end{array}$} & \multicolumn{5}{|c|}{ Coal samples (heating value, Btu/lb) } \\
\hline & & $\begin{array}{c}\text { Odagbo } \\
(9,715.74)\end{array}$ & $\begin{array}{c}\text { Owukpa } \\
(11,396.65)\end{array}$ & $\begin{array}{c}\text { Ezimo } \\
(9,010.70) \\
\end{array}$ & $\begin{array}{c}\text { Amansiodo } \\
(11,813.65)\end{array}$ & $\begin{array}{c}\text { Inyi } \\
(8,335.76)\end{array}$ \\
\hline Bituminous high volatile $\mathrm{B}$ & $13,000-14,000$ & & & & & \\
\hline Bituminous high volatile $\mathrm{C}$ & $10,500-13,000$ & & & & $\checkmark$ & \\
\hline Subbituminous A & $10,500-11,500$ & & $\checkmark$ & & & \\
\hline Subbituminous B & $9,500-10,500$ & $\checkmark$ & & & & \\
\hline Subbituminous C & $8,300-9,500$ & & & $\checkmark$ & & $\checkmark$ \\
\hline Lignite A & $6,300-8,300$ & & & & & \\
\hline Lignite B & $<6,300$ & & & & & \\
\hline
\end{tabular}

TABLE 9: Ash and sulphur classification of the five coal samples.

\begin{tabular}{|c|c|c|c|c|c|c|}
\hline \multirow{2}{*}{ Classification } & \multirow{2}{*}{ Composition range a.r. (\%) } & \multicolumn{5}{|c|}{ Coal samples (heating value, Btu/lb) } \\
\hline & & Odagbo & Owukpa & Ezimo & Amansiodo & Inyi \\
\hline \multicolumn{7}{|c|}{ Ash content } \\
\hline High ash & $>15.0$ & & & $\checkmark$ & & $\checkmark$ \\
\hline Medium ash & $8.0-15.0$ & & & & $\checkmark$ & \\
\hline Low ash & $<8.0$ & $\checkmark$ & $\checkmark$ & & & \\
\hline \multicolumn{7}{|c|}{ Sulphur content } \\
\hline High sulphur & $>3.0$ & & & & & \\
\hline Medium sulphur & $1.0-3.0$ & $\checkmark$ & & & & \\
\hline Low sulphur & $<1.0$ & & $\checkmark$ & $\checkmark$ & $\checkmark$ & $\checkmark$ \\
\hline
\end{tabular}

Inyi are both subbituminous $\mathrm{C}$ coals. This classification agrees with previously published data [23].

Ash and Sulphur Classification of Analysed Coal Samples. From results of proximate and ultimate analyses, the ash and sulphur classifications of the coal samples were obtained. This is as shown in Table 9.

Table 9 shows that Ezimo and Inyi coals are both high ash coals. Amansiodo coal is a medium ash coal, while Odagbo and Owukpa coals are low ash coals. Odagbo coal is a medium sulphur coal, while Owukpa, Ezimo, Amansiodo, and Inyi coals are all low sulphur coals.

3.7. Suitability of Analysed Coal Samples for Pulverised CoalFired Power Generation. Pulverised coal combustion is the most commonly used method in coal-fired power plants. This technology is well developed, and there are thousands of units around the world, accounting for well over $90 \%$ of coal-fired capacity. Pulverised coal combustion can be used to fire a wide variety of coals, although it is not always appropriate for those with a high ash content [24]. Results of the analysis of the coal samples were benchmarked with requirements of existing pulverised coal combustion plants from around the world. Modern pulverised coal combustion power stations have been designed to make use of low grade coals with ash contents as high as $45 \%$, sulphur contents as high as $1.7 \%$, and moisture contents as high as $58 \%$. Environmental regulations have been the only limiting factor in the actual use of these low grade coals [25].

Table 8 shows that Amansiodo coal is the only bituminous coal among the coals analysed. As a result of this, Table 10 compares all test results obtained for Amansiodo coal with the requirements arising from both the literature and a survey of requirements of actual PC power plant operators to determine its suitability for pulverised bituminous coalfired power generation. This comparison clearly shows that the tested properties of Amansiodo coal, while meeting most of the requirements, exceed or fall below the benchmark in volatile matter content (slightly higher), nitrogen (higher), and sodium oxide in its ash (lower). Chlorine content, Hardgrove Grindability Index (HGI), sulphite in ash, and petrographic analysis were not carried out on this coal and so no comparison is provided.

Further still the characteristics of the subbituminous coal used by Genesee 3 phase power station in Canada (International Energy Agency) [3] were compared with the remaining four samples which have been confirmed to be subbituminous coals. This comparison is only limited to gross calorific value, ash, moisture, and sulphur contents.

Table 11 shows that the sulphur contents of Odagbo, Owukpa, Ezimo, and Inyi coals exceed the benchmark, while the ash contents of Ezimo and Inyi coals also exceed the benchmark. Irrespective of the deficiencies noted, corrections can be effected through a coal beneficiation process and blending with other coals of better properties.

Suitability of Analysed Coal Samples for Circulating Fluidised Bed Combustion (CFBC) Power Generation. Circulating fluidised bed combustion (CFBC) units can tolerate a wide variety of coals and particle sizes and, because of their low operating temperatures and staged combustion, produce low levels of $\mathrm{NO}_{x}$ relative to PC boilers. The lower operating 
TABLE 10: Comparison of properties of Amansiodo coal with published bituminous coal quality requirements for pulverised coal-fired plants.

\begin{tabular}{|c|c|c|c|}
\hline Parameter & Desired values & Typical limits* & Amansiodo coal \\
\hline Heating value, $\mathrm{MJ} / \mathrm{kg}$ ar & High & Min 24-25 (23) & $27.48^{\#}$ \\
\hline Moisture, \% ar & $4-8$ & $\operatorname{Max} 12$ & $5.4^{\#}$ \\
\hline \multirow{2}{*}{ Volatile matter, $\% \mathrm{mf}$} & $20-35$ & Min 20 (side-fired furnaces) & $38.1^{\#}$ \\
\hline & $15-20$ & Max 20 (down-fired furnaces) & $38.1^{\dagger}$ \\
\hline Ash, \% mf & Low & $\operatorname{Max} 15-20(\max 30)$ & $8.6^{\#}$ \\
\hline Sulphur, \% daf & Low $(<1 \%)$ & Dependent on local pollution regulations & $0.92^{\#}$ \\
\hline Nitrogen, \% daf & Low & (0.8-1.1) dependent on local pollution regulations & $1.58^{\dagger}$ \\
\hline Chlorine & Low & Max $0.1-0.3(\max 0.5)$ & Not analysed \\
\hline HGI & High & Min $50-55(\min 39)$ & Not analysed \\
\hline \multicolumn{4}{|c|}{ Ash analysis, wt\% ash } \\
\hline Silicon dioxide & & $(45-75)$ & $58.94^{\#}$ \\
\hline Aluminium oxide & & $(15-35)$ & $29.13^{\#}$ \\
\hline Titanium oxide & & $(0.4-2.2)$ & $2.13^{\#}$ \\
\hline Ferric oxide & & $(1-12)$ & $6.90^{\#}$ \\
\hline Calcium oxide & & $(0.1-2.3)$ & $0.34^{\#}$ \\
\hline Magnesium oxide & & $(0.2-1.4)$ & $0.35^{\#}$ \\
\hline Sodium oxide & & $(0.1-0.9)$ & $0.06^{\dagger}$ \\
\hline Potassium oxide & & $(0.8-2.6)$ & $1.32^{\#}$ \\
\hline Sulphite & & $(0.1-1.6)$ & Not analysed \\
\hline Phosphorus pentoxide & & $(0.1-1.5)$ & $0.22^{\#}$ \\
\hline \multicolumn{4}{|c|}{ Ash fusion temperatures, ${ }^{\circ} \mathrm{C}$} \\
\hline Initial deformation & High & $(>1075)$ & $>1550^{\#}$ \\
\hline Softening & High & $(>1150)$ & $>1550^{\#}$ \\
\hline Hemispherical & High & $(>1180)$ & $>1550^{\#}$ \\
\hline Fluid & High & $(>1225)$ & $>1550^{\#}$ \\
\hline \multicolumn{4}{|c|}{ Maceral analysis, $\%$} \\
\hline Vitrinite & & $55-80$ & Not analysed \\
\hline Exinite & & $5-15$ & Not analysed \\
\hline Inertinite & & $10-25$ & Not analysed \\
\hline
\end{tabular}

* Typical limits refer to those commonly quoted; those in brackets indicate outer limits acceptable in some cases.

${ }^{\#}$ Acceptable. ${ }^{\dagger}$ Not acceptable.

TABLE 11: Comparison of four coal samples with characteristics of subbituminous coal used by Genesee Phase 3 power station in Canada.

\begin{tabular}{|c|c|c|c|c|c|}
\hline \multirow{2}{*}{ Parameters } & \multirow{2}{*}{ Genesee Phase 3, Canada } & \multicolumn{4}{|c|}{ Coal samples } \\
\hline & & Odagbo & Owukpa & Ezimo & Inyi \\
\hline Coal type & Subbituminous & Subbituminous & Subbituminous & Subbituminous & Subbituminous \\
\hline Gross calorific value, $\mathrm{MJ} / \mathrm{kg}$ & 17.9 & $22.60^{\#}$ & $26.51^{\#}$ & $20.96^{\#}$ & $19.39^{\#}$ \\
\hline Ash, $\%$ & 19.4 & $5.3^{\#}$ & $3.3^{\#}$ & $23.4^{\dagger}$ & $30.4^{\dagger}$ \\
\hline Moisture, \% & 20 & $14.9^{\#}$ & $11.5^{\#}$ & $6.6^{\#}$ & $3.8^{\#}$ \\
\hline Sulphur, \% & 0.2 & $1.07^{\dagger}$ & $0.60^{\dagger}$ & $0.56^{\dagger}$ & $0.56^{\dagger}$ \\
\hline
\end{tabular}

${ }^{\#}$ Acceptable. ${ }^{\dagger}$ Not acceptable.

temperature is also ideally suitable for the in situ capture of sulphur dioxide $\left(\mathrm{SO}_{2}\right)$. The efficiency of CFBC units is similar to that of PC units [25]. This is further reinforced by the conclusion of [18] that circulating fluidised bed technology can be used to fire the entire range of high and low quality coals. Thus, all the five coal samples can be utilised for power generation using this technology.

CFBC technology was developed to burn low grade and/or difficult-to-burn fuels. Many existing CFBC units are fired with waste coal and serve to clean up waste piles left over from mining activities. CFBC technology has been employed for power generation for over 25 years and the technology is still evolving. The poorer economy of scale and lower efficiency of the CFBC plants result in higher plant costs and have limited its deployment [26].

\section{Conclusions}

Based on analysis of tests carried out, the coals have been classified in terms of rank, grade, and type. Amansiodo 
coal is a bituminous, low sulphur, and medium ash coal, while Owukpa coal is a subbituminous A, low sulphur, low ash coal rich in huminites. In addition, Odagbo coal is a subbituminous B, medium sulphur, low ash coal rich in huminites, Ezimo coal is a subbituminous C, low sulphur, high ash coal, and Inyi coal is a subbituminous C, low sulphur, high ash coal.

The ease of combustion of the coal samples in decreasing order is Odagbo < Owukpa $<$ Inyi $<$ Ezimo $<$ Amansiodo. While the ignition temperatures of the coals increase with decreasing volatile matter content, their calorific values are strongly correlated with the fixed carbon, elemental carbon, volatile matter, and hydrogen contents in decreasing order.

Benchmarking the properties of the five coal samples against requirements of existing PC plants from around the world shows that these coals meet most requirements. Deficiencies observed can be corrected through beneficiation and/or blending with coals of better properties. The five coal samples analysed can be used for power generation using circulating fluidised bed combustion (CFBC) technology. CFBC technology was developed to burn low grade and/or difficult-to-burn fuels and can therefore tolerate a wide variety of coals and particle sizes.

\section{Competing Interests}

The authors declare no conflict of interests.

\section{References}

[1] A. S. Sambo, B. Garba, I. H. Zarma, and M. M. Gaji, "Electricity generation and the present challenges in the Nigerian power sector," 2009, http://www.energy.gov.ng/.

[2] World Coal Association, Coal Matters 3/Coal and Electricity Generation, 2012, http://www.worldcoal.org/resources/ wca-publications.

[3] International Energy Agency, "Fossil fuel-fired power generation: case studies of recently constructed coal- and gas-fired power plants," 2007, http://www.iea.org/publications/ freepublications/publication/fossil-fuel-fired-powergeneration .html.

[4] The Presidency. Federal Republic of Nigeria, "National energy policy," 2003, http://www.energy.gov.ng/.

[5] IEA, Key Energy Statistics 2012, IEA, 2012.

[6] Ministry of Solid Minerals Development, Investment and Mining Opportunities, Ministry of Solid Minerals Development, Abuja, Nigeria, 2008, https://www.pdffiller.com/250587217.

[7] Key world statistics 2013 IEA page 11 gas, page 13 oil, page 15 coal.

[8] A. Nasir, S. N. Mohammed, and A. Mohammed, "Performance of enugu sub-bituminous coal in fluidized bed combustor," in Proceedings of the World Congress on Engineering (WCE '15), vol. 2, pp. 1102-1106, London, UK, July 2015.

[9] A. Jauro and C. J. Chukwu, "Production of formed coke from Nigerian coals," Petroleum \& Coal, vol. 53, no. 1, pp. 22-25, 2011.

[10] W. I. A. Aderonpe, "Coal blending: application to Nigerian coals for the iron and steel industries," in Nigerian Coal: A Resource for Energy and Investments, H. C. Okolo and M. C. Mkpadi, Eds., pp. 125-137, RMRDC, Abuja, Nigeria, 1996.
[11] A. A. Afonja, "Production of metallurgical coke from noncoking coals," in Nigerian Coal: A Resource for Energy and Investments, H. C. Okolo and M. C. Mkpadi, Eds., pp. 89-105, RMRDC, Abuja, Nigeria, 1996.

[12] B. G. Miller, Coal EnergySytems, Elsevier, Academic Press, New York, NY, USA.

[13] A. M. Carpenter, S. Niksa, SRI International, D. H. Scott, and Z. Wu, Fundamentals of Coal Combustion, IEA Clean Coal Center, London, UK, 2007.

[14] J. Zactruba, Burning Coals in Power Plants-Calorific Value and Moisture, 2009.

[15] G. Marlair, C. Cwiklinski, and A. Tewarson, "An analysis of some practical methods for estimating heats of combustion in fire safety studies," in Proceedings of the International Interflam Conference (Interflam '99), Edinburgh, UK, June 1999.

[16] W. Boie, Wissenschaftliche Zeitschrift der Technischen Hochschule Dresden, vol. 2, 1952-1953.

[17] K. Annamalai, J. M. Sweeten, and S. C. Ramalingam, "Estimation of gross heating values of biomass fuels," Transactions of the ASAE, vol. 30, no. 4, pp. 1205-1208, 1987.

[18] S. J. Goidich, "Supercritical boiler options to match fuel combustion characteristics," Indian Journal of Power and River Valley Development, vol. 60, no. 5, p. 81, 2010.

[19] S. P. Marinov, L. Gonsalvesh, M. Stefanova et al., "Combustion behaviour of some biodesulphurized coals assessed by TGA/DTA," 2009, http://research.sabanciuniv.edu/12435/1/ Thermochimica_Acta_75157.pdf.

[20] S. Kizgut, D. Cuhadaroğlu, and İ. Toroğlu, "Thermogravimetric characterisation of Turkish bituminous coals for combustion," Turkish Journal of Chemistry, vol. 27, pp. 521-528, 2003.

[21] R. Falcon and A. J. Ham, "The characterization of southern African coals," Journal of the Southern African Institute of Mining and Metallurgy, vol. 88, no. 5, pp. 145-161, 1988, https:// www.yumpu.com/en/document/view/13417142/the-characteristics-of-southern-african-coals-saimm.

[22] J. C. Crelling, E. J. Hippo, B. A. Woerner, and D. P. West Jr., "Combustion characteristics of selected whole coals and macerals," Fuel, vol. 71, no. 2, pp. 151-158, 1992.

[23] M. M. Kibiya, Properties of some Nigerian coals for power generation [M.S. thesis], Ahmadu Bello University, Zaria, Nigeria, 2012.

[24] International Energy Agency, "Pulverized coal combustion," 2010, http://www.iea-coal.org.uk/site/2010/database-section/ clean-coal-technologies.

[25] K. Burnard and S. Bhattacharya, "Power generation from coal: ongoing developments and outlook," Information Paper, International Energy Agency, Paris, France, 2011.

[26] IEA Clean Coal Center, "Developments in circulating fluidised bed combustion," Profiles issue no. 13/7, 2013, http://www iea-coal.org.uk/documents/83172/8753/Developments-in-circulating-fluidised-bed-combustion,-CCC/219. 


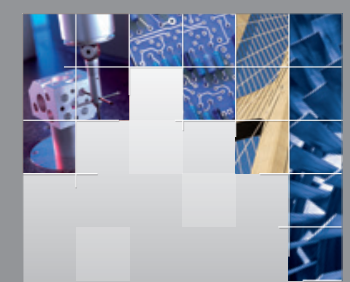

\section{Enfincering}
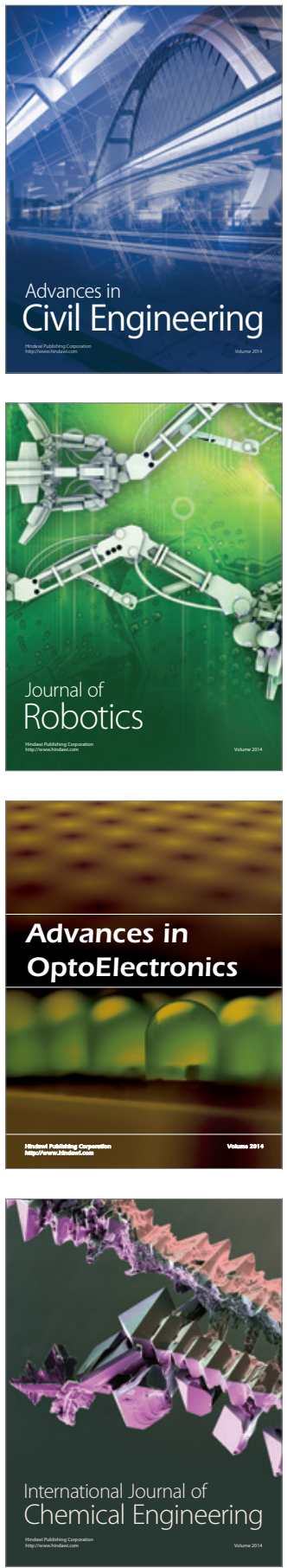

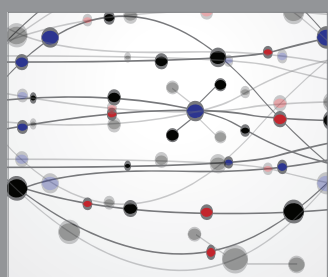

The Scientific World Journal

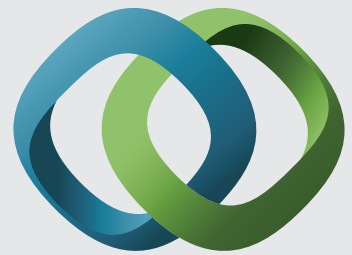

\section{Hindawi}

Submit your manuscripts at

http://www.hindawi.com
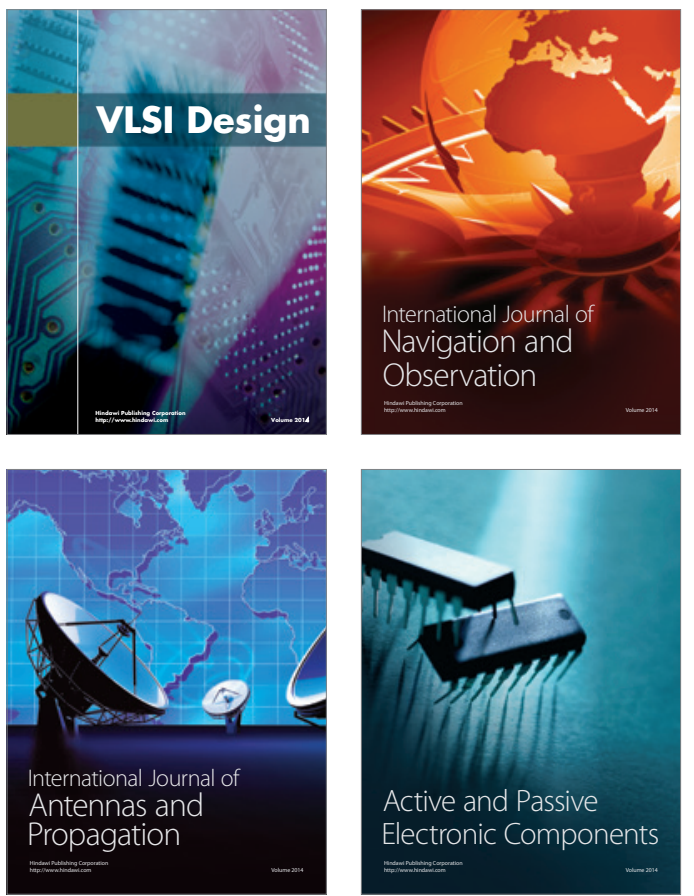
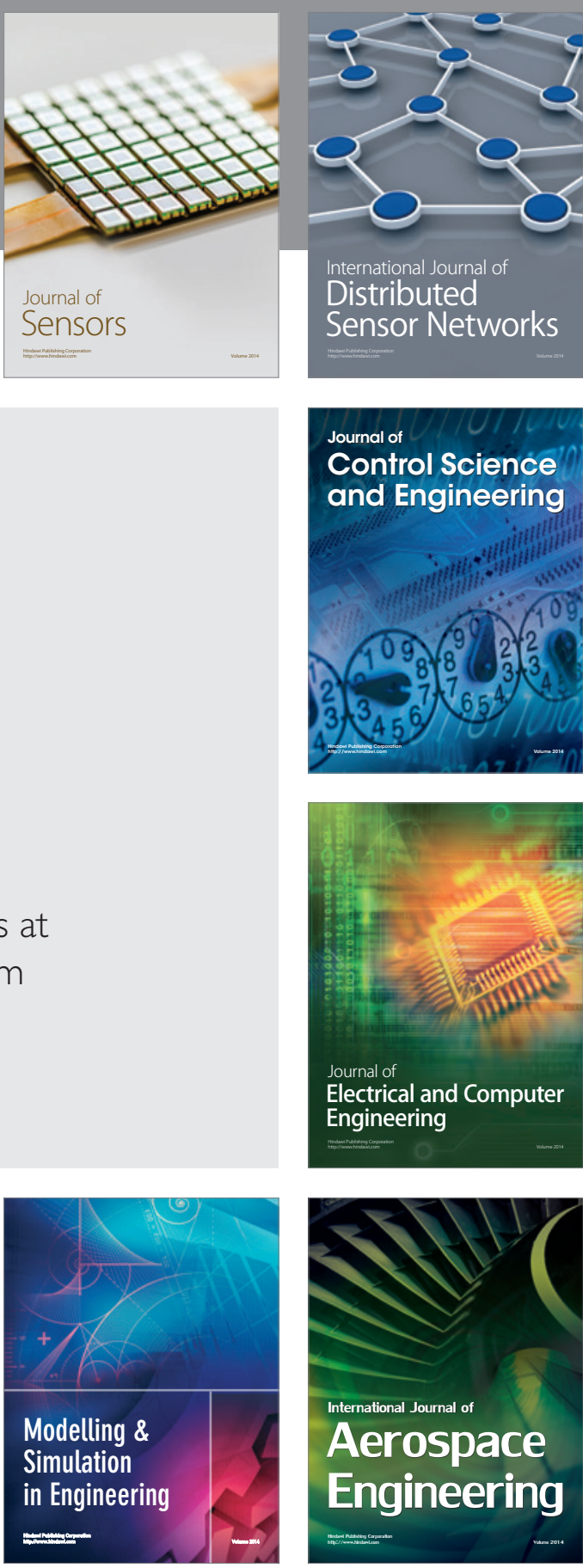

International Journal of

Distributed

Sensor Networks

Journal of

Control Science

and Engineering
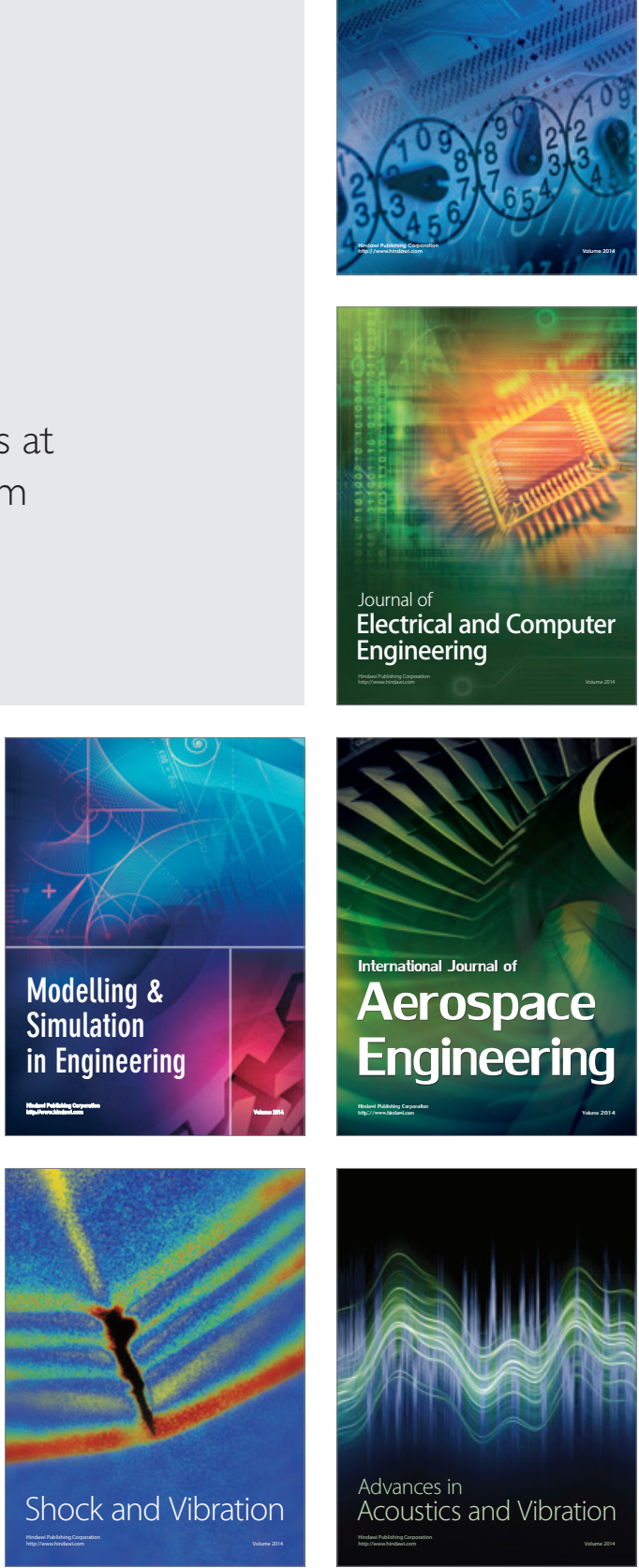